\title{
Ashmole's halo: direct evidence for prey depletion by a seabird
}

\author{
V. L. Birt, T. P. Birt, D. Goulet ${ }^{*}$, D. K. Cairns**, W. A. Montevecchi \\ Departments of Psychology and Biology and Newfoundland Institute for Cold Ocean Science, Memorial University of \\ Newfoundland, St. John's, Newfoundland A1B 3X9, Canada
}

\begin{abstract}
Fish population densities were measured at various distances from 2 large colonies of double-crested cormorants Phalacrocorax auritus to test the hypothesis that seabirds deplete prey close to their colonies. Fish densities were significantly lower in bays used by cormorants for feeding than in those outside their foraging range. Our findings provide direct evidence for prey depletion, and support Ashmole's (1963) hypothesis that seabird populations are limited by food supplies during the breeding season.
\end{abstract}

\section{INTRODUCTION}

Ashmole (1963) proposed that seabird populations in tropical and possibly higher latitude regions are regulated by food supply during the breeding season. He suggested that feeding activity creates prey-depleted 'halos' around colonies, ultimately resulting in reduced reproductive success and increased age at first breeding. Several lines of indirect evidence support this hypothesis: bioenergetics models indicate that food requirements at large colonies may be a significant fraction of available fish stocks (reviewed by Furness 1982); Furness \& Birkhead (1984) found that colony sizes of 4 seabird species in Great Britain were negatively correlated with numbers of conspecifics at other colonies within the foraging ranges; Gaston et al (1983) and Hunt et al. (1986) reported negative correlations between colony sizes and fledging masses for 2 murre species; and Hunt et al. (1986) found negative correlations between colony sizes and chick growth rates for 3 Nearctic seabird species.

Such indirect support for Ashmole's hypothesis is subject to alternative interpretations, and due to practical difficulties in censusing the mobile and patchily distributed prey of most seabirds, prey depletion has

\footnotetext{
- Present address: Department of Marine Science, University of Puerto Rico, Mayaguez, Puerto Rico 00708, USA.

- Present address: Science Branch, Department of Fisheries and Oceans, Box 5030, Moncton, New Brunswick E1C 986 . Canada
}

never been tested directly (Birkhead \& Furness 1985). Double-crested cormorants Phalacrocorax auritus feed predominantly on relatively sedentary benthic fishes (Dunn 1975, Pilon et al. 1983, Gallant 1986, V. L. Birt unpubl.) which can be systematically censused by divers, so are ideal subjects for an investigation of prey depletion. In the present study, fish densities were measured relative to distance from 2 cormorant colonies to test the hypothesis that densities decrease with proximity to colonies.

\section{METHODS}

Ram Island $\left(46^{\circ} 32^{\prime} \mathrm{N}, 63^{\circ} 45^{\prime} \mathrm{W}\right.$; Fig. 1), located in Malpeque Bay, Prince Edward Island, Canada, is the site of a large (2800 pairs, Gallant 1986), recently established (ca 1976) double-crested cormorant colony; an additional 530 pairs breed at Cape Tyron, $19 \mathrm{~km}$ to the east (Gallant 1986). Cormorants from these sites regularly feed in nearby Malpeque, New London and Bedeque Bays but are rarely seen in Tracadie and St. Peter's Bays, which are over $40 \mathrm{~km}$ away and outside the cormorants' typical foraging range (Mendall 1936, V. L. Birt unpubl.; Fig. 1). Small numbers of doublecrested cormorants also nest at Durell Point and Cherry Island (Fig. 1), but birds from these colonies do not regularly feed in St. Peter's or other north shore bays.

Numbers and species of fish in Malpeque Bay (15 transects) and New London, Tracadie and St. Peter's 




Fig. 1. Study bays and colonies of doublecrested cormorants on Prince Edward Island. (MB) Malpeque Bay; (NLB) New London Bay; (TB) Tracadie Bay; (SPB) St. Peter's Bay; (BB) Bedeque Bay. (RI) Ram Island, 2800 nests; (CT) Cape Tryon, 530 nests; (DP) Durell Point, 27 nests; (CI) Cherry Island, 450 nests (Gallant 1986)

Bays ( 5 transects each) were recorded in July 1985 by 2 SCUBA-equipped divers swimming $1 \mathrm{~m}$ apart along a $60 \mathrm{~m}$ lead-weighted transect line. Dive sites were approximately evenly spaced throughout areas within the foraging depths of double-crested cormorants $(1.5$ to $8 \mathrm{~m}$, Lewis 1929, Ross 1973), and data for the 2 divers were pooled. Numbers of cormorants in the vicinities of transects were also recorded. Most breeding cormorants had large chicks in July, although there was considerable variation in nesting chronology.

\section{RESULTS AND DISCUSSION}

All 4 bays were silty with Zostera marina in shallow areas and had similar depths, visibilities, temperatures and bottom morphologies, although St. Peter's Bay was slightly deeper and colder (Table 1). Numbers of cormorants near transects in Malpeque and New London
Bays were significantly higher than in Tracadie and St. Peter's Bays (Table $1 ;$ Kruskal-Wallis analysis of variance corrected for ties; $\mathrm{H}=11.3 ; \mathrm{n}=30 ; \mathrm{p}=0.01$ ). Flounders (lengths 5 to $25 \mathrm{~cm}$ ), cunners $(<5 \mathrm{~cm}$ ) and three-spined sticklebacks $(\sim 5 \mathrm{~cm})$ were the most common fish seen. Densities of (1) flounders and (2) all fish types eaten by cormorants were significantly higher in Tracadie and St. Peter's Bays than in Malpeque and New London Bays (Table 1; Kruskal-Wallis analysis of variance corrected for ties; $\mathrm{H}=23.8, \mathrm{n}=30, \mathrm{p}<0.001$ for flounders; $\mathrm{H}=12.2, \mathrm{n}=30, \mathrm{p}=0.007$ for all fish). Densities of flounders and of all fish types eaten by cormorants decreased with proximity to nearest colony (Fig. 2; Spearman's Rank Correlation; $r_{s}=0.75, n=30$, $p<0.0001$ for flounders; $r_{s}=0.42, n=30, p=0.02$ for all fish). Large numbers of cunners were seen in Malpeque Bay, but few were recorded in the other bays.

An analysis of stomach contents of Ram Island cormorants in 1985 revealed mostly cunners, flounders

Table 1. Fhysical and bıotic features of 4 Prince Edward Island bays. Means \pm 1 sd

\begin{tabular}{|c|c|c|c|c|c|c|c|c|}
\hline \multirow[t]{2}{*}{ Bay } & \multirow{2}{*}{$\begin{array}{l}\text { Mean } \\
\text { transect } \\
\text { depth } \\
(\mathrm{m})\end{array}$} & \multirow{2}{*}{$\begin{array}{l}\text { Temp. } \\
\left({ }^{\circ} \mathrm{C}\right) \\
\text { bottom- } \\
\text { surface }\end{array}$} & \multirow{2}{*}{$\begin{array}{l}\text { Mean } \\
\text { dist. to } \\
\text { nearest } \\
\text { coiony } \\
(\mathrm{km})\end{array}$} & \multirow{2}{*}{$\begin{array}{l}\text { Mean } \\
\text { number } \\
\text { cormorants } \\
\text { near } \\
\text { transects }\end{array}$} & \multicolumn{4}{|c|}{ Mean number of fish } \\
\hline & & & & & Flounder ${ }^{A}$ & Cunner ${ }^{3}$ & Other & Total \\
\hline Malpeque & $3.0 \pm 1.3$ & $1.5-15$ & $4.8 \pm 3.2$ & $2.9 \pm 2.5$ & $0.5 \pm 1.6$ & $6.0 \pm 12.3$ & $0.2 \pm 0.6^{\mathrm{C}}$ & $6.7 \pm 12.3$ \\
\hline New London & $4.6 \pm 0.6$ & $16-17$ & $6.6 \pm 0.6$ & $4.0 \pm 4.3$ & $0.4 \pm 0.9$ & $0.2 \pm 0.4$ & $0.0 \pm 0.0$ & $0.6 \pm 0.9$ \\
\hline Tracadie & $3.8 \pm 0.7$ & $17-19$ & $42.4 \pm 0.8$ & 0 & $17.6 \pm 6.8$ & $0.2 \pm 0.4$ & $6.2 \pm 13.3^{\mathrm{D}}$ & $24.0 \pm 16.8$ \\
\hline St Peter's & $5.1 \pm 1.2$ & $12-22$ & $64.1 \pm 3.6$ & $0.2 \pm 0.4$ & $17.0 \pm 6.2$ & $0.2 \pm 0.4$ & $0.0 \pm 0.0$ & $17.2 \pm 6.1$ \\
\hline $\begin{array}{l}\text { A Family Pleu } \\
\text { B Tautogolabr } \\
\text { C } 1 \text { eelpout } G \\
\text { D } 31 \text { three-spt }\end{array}$ & $\begin{array}{l}\text { nectidae } \\
\text { sadspersu } \\
\text { nnelis viric } \\
\text { ed stickleb }\end{array}$ & $\begin{array}{l}\text { sculpin } \lambda \\
\text { Gasteros }\end{array}$ & $\begin{array}{l}\text { xocephalus } \\
\text { Is aculeatus }\end{array}$ & . 1 adult Am & can eel Ang & Ula rostrata & & \\
\hline
\end{tabular}


Fig. 2. Numbers of fish in relation to distance of transect from nearest double-crested cormorant colony. (-) Malpeque Bay; (o) transects in Malpeque Bay with large numbers of cunners; $(*)$ New London Bay; (ム) Tracadie Bay; (ロ) St. Peter's Bay

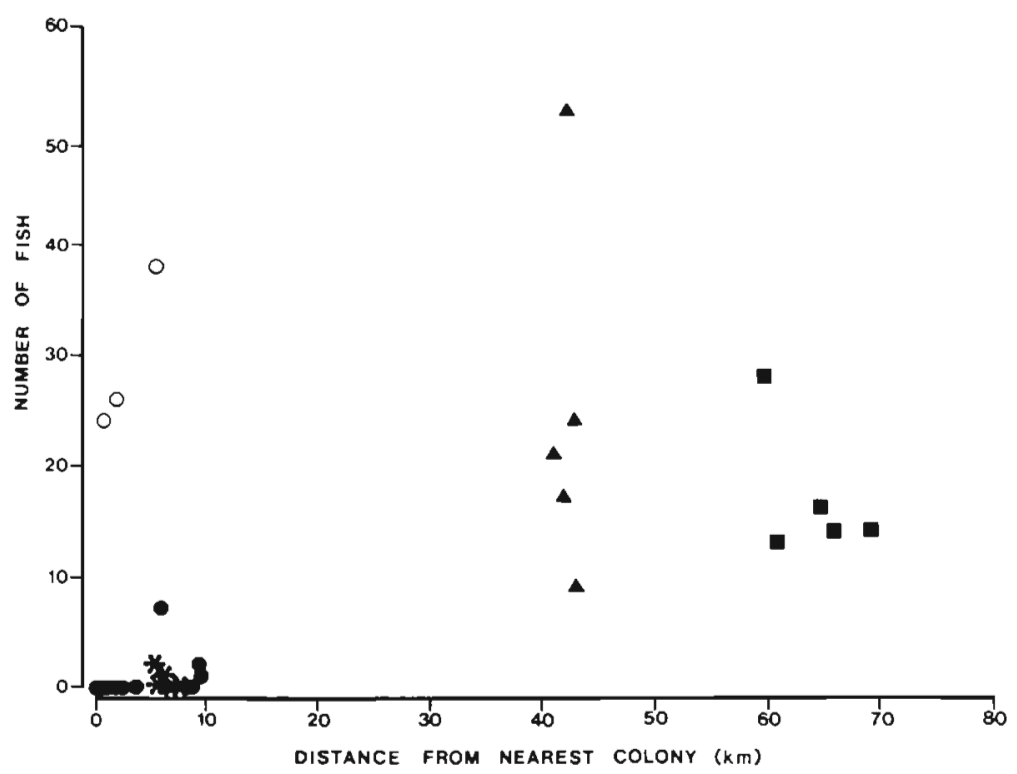

The observation of large numbers of cunners on some transects in Malpeque Bay (Table 1, Fig. 2) does not refute the prey depletion hypothesis; these fish were all juveniles and occurred only in rocky areas. This type of habitat, which provides refuge for small fish, was not encountered in other bays. The absence of adult cunners in Malpeque Bay suggests that juveniles are recruited from outside the bay and are consumed before attaining adult size.

Double-crested cormorant populations have increased dramatically in northeastern North America in recent years, partly due to decreased human disturbance (Vermeer \& Rankin 1984). If food supplies replace human factors in limiting populations, then colonies may be expected to expand until mortality, migration and reproductive success produce a balance between colony size and available food (Ashmole 1963). Ram Island cormorants now feed primarily in Bedeque Bay, $16 \mathrm{~km}$ away and near the limit of their foraging range (Mendall 1936), and breeding success and population growth may be predicted to decline in the near future. It should be emphasized that cormorants have not been found to feed extensively on commercially important fish species (such as salmon and trout), and that there is no commercial finfish fishery in the bays used by Ram Island cormorants. Much more research is needed to determine both whether other colonial seabirds deplete food resources, and how changes in prey density and distribution affect reproductive success, mortality and migration. Seabird populations that are limited by food may be vulnerable to competition with commercial fisheries.

Acknowledgements. We thank G. G. Hogan, faculty and staff of the Department of Biology (University of Prince Edward 
Island), and R. Dibblee of the Prince Edward Island Fish and Wildlife Division for field equipment and assistance. A. Gallant generously shared unpublished data. D. C. Schneider and A. J. Gaston provided helpful comments on the manuscript. Research was supported by NSERC Individual Operating Grant A0687 (WAM) and postgraduate scholarships (V.L.B. and T.P.B.). This is report \#114 from the Newfoundland Institute for Cold Ocean Science.

\section{LITERATURE CITED}

Ashmole, N. P. (1963). The regulation of numbers of tropical oceanic birds. Ibis 103b: 458-473

Birkhead, T R., Furness, R. W (1985). Regulation of seabird populations. In: Sibly, R. M., Smith, R. H. (ed.) Behavioural ecology, ecological consequences of adaptive behaviour. Blackwell, London, p. 147-167

Dunn, E. H. (1975). Caloric intake of nestling double-crested cormorants. Auk 92: 553-565

Furness, R. W. (1982). Competition between fisheries and seabird communities. Adv. mar. Biol. 20: 225-307

Furness, R. W. Birkhead, T. R. (1984). Seabird colony distributions suggest competition for food supplies during the breeding season. Nature, Lond. 311: 655-656

Gallant, A. (1986). Summer food of the double-crested cormorant (Phalacrocorax auritus L.) on Prince Edward Island: a preliminary report. Unpubl Report, Fish \& Wildlife Div., P.E.I. Dept. Community \& Cultural Affairs, Charlottetown

Gaston, A. J., Chapdelaine, G., Noble, D. (1983). The growth of thick-billed murre chicks at colonies in Hudson Strait: inter- and intra-colony variation. Can. J. Zool. 61: $2465-2475$

Hunt, G. L., Jr., Eppley, Z. A., Schneider, D. C. (1986). Reproductive performance of seabirds: the importance of population and colony size. Auk 103: 306-317

Kury, C. R. (1968). Difference in weight of male and female cormorants. Auk 85: 513

Lasiewski, R. C., Dawson, W. R. (1967). A re-examination of the relation between standard metabolic rate and body weight in birds. Condor $69 ; 13-23$

Lewis, H. F. (1929). The natural history of the double-crested cormorant. Miller, Ottawa

Mendall, H. L. (1936). The home life and economic status of the double-crested cormorant [Phalacrocorax auritus auritus (Lesson)]. Maine Bull. 38 (3): 1-1.59

Needler, A. W H. (1940). A preliminary list of the fishes of Malpeque Bay. Proc. N.S. Inst Sci. 20 (2): 33-41

Pilon, C., Burton, J., McNeil, R. (1983). Summer food of the great and double-crested cormorants on the Magdalen Islands, Quebec. Can. J. Zool. 61: 2733-2739

Ricklefs, R. E. (1974). Energetics of reproduction in birds. In: Paynter, R. A., Jr. (ed.) Avian energetics. Publ. Nuttall Ornithol. Club No. 15, Cambridge, p. 152-297

Ross, R. K. (1973). A comparison of the feeding and nesting requirements of the great cormorant (Phalacrocorax carbo L.) and double-crested cormorant ( $P$. auritus Lesson) in Nova Scotia. M.S. thesis, Dalhousie Univ.

Stafford, J. (1912). On the fauna of the Atlantic Coast of Canada. Contrib. Can. Biol. 1906-10: 37-44

Vermeer, K., Rankin, L. (1984). Population trends in nesting double-crested and pelagic cormorants in Canada. Murrelet 65: 1-9 